JOURNAL OF AWARENESS

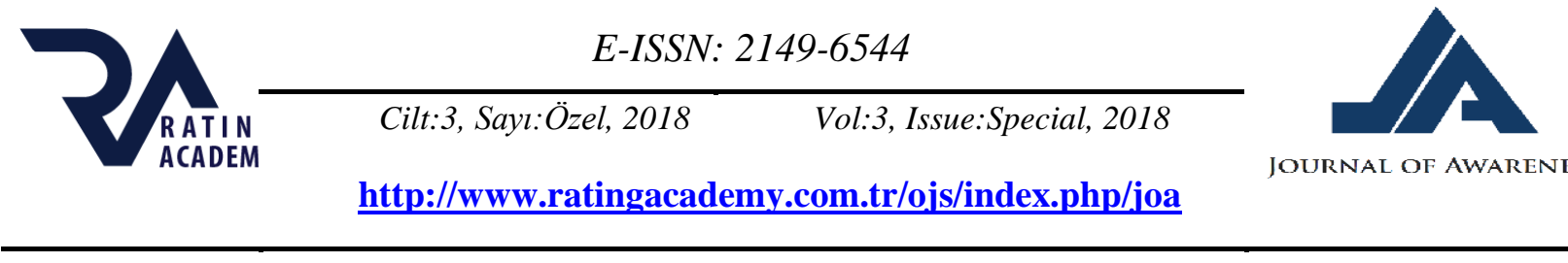

\title{
CONFLICTING INTERACTION AS A PSYCHOLOGICAL RISK FACTOR IN INTRA-FAMILY RELATIONS*
}

\author{
Phd, Docent Nurali CHALABIYEV \\ (Zarbali oghlu) \\ Sheki branch of Azerbaijan \\ State Pedagogical University \\ E-mail: $\underline{n}$ chelebiyev@mail.ru
}

\begin{tabular}{l|l}
\hline ARTICLE INFO & \multicolumn{1}{c}{ ABSTRACT } \\
\hline $\begin{array}{l}\text { Keywords: } \\
\begin{array}{l}\text { Conflict, husband and wife } \\
\text { relationships, interaction, } \\
\text { intergenerational conflicts, } \\
\text { role conflicts. }\end{array}\end{array}$ & $\begin{array}{l}\text { Family has a specific role in social structure of society as a great social discovery } \\
\text { of humanity. As a kind of social unity, family consisting of married couple and } \\
\text { their children performs the functions of vital importance and it is a source of } \\
\text { physical and moral psychological health of human. Intra-family relations, with } \\
\text { being a main factor that originated psychological climate of family, have an } \\
\text { important role in lifestyle and cultural standards of family. However, a family life } \\
\text { is not completely comfort. It is a source of happiness, as well as a source of } \\
\text { psychological trauma. Scientific researches prove that, 80-85 percent of families }\end{array}$ \\
\hline DOI: & $\begin{array}{l}\text { have been encountered conflicts in this or another way. As many other conflicts, } \\
\text { family conflicts may be constructive and destructive too. Destructive conflicts } \\
\text { impair spiritual foundations of family and lead to intensifying intra-family } \\
\text { contradictions, domestic violence and in most cases, divorces. To control } \\
\text { conflicting situation, to attain a constructive solve of collusions, family members } \\
\text { must have a particular abilities. }\end{array}$ \\
\hline
\end{tabular}

\section{CONFLICTING INTERACTION AS A PSYCHOLOGICAL RISK FACTOR IN INTRA-FAMILY RELATIONS}

\subsection{Introduction}

The life of each family influences society's life with its multicolored and complex appearances. As well as the society has an influence to the formation of any family type, the impact of the family on community development and formation of its life style is not less. Family has an important role on economic and spiritual progress of society, education of the growing generation and happiness of each human.

In our contemporary era, under the influence of global integration, covering the whole world, as being in many countries, there have been occurred new life standards and thinking norms in Azerbaijan too. Scientific and technological achievements deeply penetrated into the family, as all areas of society, and along with positive changes in many respects, also with its negative impacts, these lead to destructive effect on Azerbaijani family that historically distinguished by its holiness and its values. Historically, Azerbaijan people highly evaluated the marriage as the foundation of family, considered the marriage as a sacred religious act, bound it with the name of blessed angels. The marriage ceremony had been considered as sacred

\footnotetext{
*Bu çalışma 15-16 Kasım 2018 tarihlerinde Baku/AZERBAYCAN'da düzenlenen "Kültürel Paradigmalar ve Yenilenen Azerbaycan" konulu Uluslararası Konferansta sunulmuş aynı isimli bildirinin gözden geçirilmiş halidir.
} 
moment, at the end of wedding party, breaking of plates had been interpreted as an expression of the desires and intentions "not to break heart" of newly married couples. That is why, the topic of family and household issues are rich with remarkable examples in Azerbaijan folklore and artistic prose.

\subsection{Main text}

In Azerbaijan, where more than $90 \%$ of population is Muslims, the family is established on national, spiritual, and religious values, along with legal norms. It is futile to talk about fully providing of people's material and spiritual needs without taking a look to the role of family, as social and economic fundament of society. And these all, firstly depend on how successful the marriage is in each newly-created family.

In many respects, the success or failure of marriage in the future depends on partner chosen for marriage, his essential personal qualities, psycho-physiological features, outlook and worldview level and values system. Successful marriage firstly depends on moral upbringing level of husband and wife, political, cultural, religious views, and tolerant attitude and patience to each others' characters. In successful families parent-children relations are based on real love, sincerity, communication, understanding each other, respect and esteem, but in unsuccessful families these indicators are not available.

People who live in hard life style with full of problems, even though have lived a long life together, actually may not be too happy. The number of miserable and unsupported women are not less, who are satisfied with their destiny and fortune, exposed to violent and cruel treatment of their alcohol abused or drug addicted husbands for the sake of their children, going on in such painful life enduring all kinds of suffering, and who are forced to avoid divorce because of negative attitude of society.

"Conflict embodies in itself also the features of ethnic group because at the same time each family includes to the content of any ethnic group. In this respect, Azerbaijani families are more closed in comparison to other ethnos and do not like to notify its own family secret to anyone". (Shiriyeva, 1998:11)

Social life of individual is a complex system of numerous joint forms of action and mutual relations with other people. Depending on their different features and personal practices, various people react differently to life situations they face. Emotional reactions of people to important, fateful events which they encounter in life show themselves in their behaviors, communications and treatments by conditioning with personal, psychological features and characteristic signs. Social life is conditioned with preserving the individual's own existence, opportunities to realize their interests, values and needs and social relations. The tensions occurring on the ground of such mutual relations lead to social disadaptation, and in its turn, this leads to negative psycho-emotional changes in psychological situation of people like stress and depression."The family doesn't always fully comply with individual requirements. First of all, because it is stable and cannot rapidly change as individual requests. In this sense, we can say that totally, conflicts between family and individuals are conditioned with changeable requirements of individual". (E.Eidemiller, V.Yustiskits, 2009:189)

Interaction in family is establihed on binding behavioral type, basing on traditions, norms and rules formed in any family. Their violation or non-observance cause to break of family's bases and its foundation. As the reasons of emergence of conflicting situations, disagreements can be considered as sufficiently durable and stable component. But along with this, its volume may change depending on the nature of relations with partner. If totally, conflict participants make positive and sympathetic feelings for each other, then their thought contradictions don't deepen and expand, ultimately, limit with concrete object or event which 
is the reason for confict. "Interpersonal relations are the relations that emerged among the people who thinks and feels in real life. These relations form the essence of communication and are specific results of it. In turn, interpersonal relations that emerged in communictation process effect to communication by defining its content and other features" $(6,: 39)$. Interpersonal relations are based on interaction and formed in its basis. Divergences and contradictions which arising from them, occuring in the process of mutual influence act as a conflicting factor and stipulate the solution of problems. The psychologists show two main kinds of thought differences'development arising from contradictions: constructive and destructive. They indicate these with the conception of "conflict'. Conflict (Latin conflictus-collision) is a clash of interest, sightings and inclinations of people in relations to each other, and serious disagreement, intensive controversy which lead to confrontation at the result. In psychological sense, a conflict is a kind of communication, basing on contradictions among people and an attempt to resolve these contradictions in the strained emotional situation. In social psychology, the concept of "conflict" is expalined as a collision of mutual opposite interests, goals, views, as well as ideologies between individuals and groups.

By referring to social researches, we can say that, at the time of conflicting mutual relation, the risk of approaching each other with psychological pressure methods, of subjects who are conflict participants, are approximately $63 \%$.

In conflicting situations, the opposing parties show contradictory behaviors to each other. Here we can include biased nature, boycott, disrespect, dissatisfaction with initiatives, threat, humiliation, social isolation, disappointment, deprivation of care, physical violence and etc.

According to one of the well-known researchers of family pyshocology problems, I.V.Grebennikov, family conflict is a serious disagreement arising from inconsistency of views, interests and needs of family members. Conflict is a high stage of contradictions' development in the system of social institutions and in the relations among the people. Conflict is based on mutual contradictions, incompatibility between at least two persons, or among the people. It is a collision of their needs, interests, goals, benefits, kinds of behaviors, set of relations, along with these, conflict is perceived as very important for the identity and groups and socially it is an event that is conditioned by individual characteristics of people's psychology. They are usually accompanied by affective behavior depending on acute emotional and alarmedconflicting situation. Family conflicts are one of the most widespread forms of conflicts. According to the experts working in the field of social psychology, in $80-85 \%$ of family are encountered conflicts in this or another way.

Russian psychologist E.V.Siderenko (1997:123-142) indicates 11 kinds of psychological effect among the people and 8 kinds of oppositions to these effects. According to him, the main factor causing open conflict in interpersonal interactions is destructive criticism. Such interaction shows itself in offensive considerations to the personality, commitments and actions of opposite party or verbal agressive movements to his address, like swearing, mockery. Destructive power of such criticism is in that, it doesnt allow a person to preserve his own personality. American researcher D.Karnegi (2014:47) believes that differences of opinion among the people are natural and unavoidable process and show that succesfully solved conflicts (both at work or in private life) raise the level of mutual respect and stipulates reinforcement of interpersonal relations.

In problematic situations conflicts are becoming more acute in family, emotional reactions of partners are getting intensive and as a result, it creates a favorable condition for escalation of conflicts. A complaint, criticism, or any heart-breaking word caused by controversial factor occurrs as a means of self-defense of opposite side, although is not related 
to the current situation. And this causes re-emergence of formerly extinguished conflict, and as a result further aggravation of new conflict. Russian pyschologist I.V.Grebennikov $(1991 ; 25)$ divides intra-family relations to 3 groups such as confrontation, existence (everyone for himself-N.Chalabiyev) and association. He notes that the fundamentals of favorable psychological atmosphere in family forms by combination of husband and wife that based on community in their ideological and spiritual views.

While in family, the culture of communication and dispute between husband and wife are low level, rudeness, the reputation of traditions, subordinating others to himself, correction motives and other cases of violence can be sources of family conflicts. By talking about this issue, D.Karnegi $(2009 ; 209)$ writes: "The most effective means invented by Devil to kill the love is jealousy and hysterical attacks. They are very effective like poison of king's cobra and definitely destroy, kill”"

Last years as being in many spheres of political, social, public and spiritual life of society, aggression and tension which accompanied by conflicts are going to increase in intrafamily mutual relations among the people. Even, many sociologists and psychologists figuratively name this situation "war of genders".

Russian psychologist A.V.Petrovski (1983:191) characterized the family as a collective and considered that first of all, in comparison to any other small groups, family has more serious role structure as a collective.

The main kinds of subjective resistance to psychological influence which lead to conflicts and their escalation are insistence, psychological self-defense and confrontation. Confrontation is an open and durable counteraction that is opposite to the position of subject which acts as an influential initiator. As well as it is an insistence on the accuracy of his position, on being right (Grishina, 2006:218-222).

The development of conflict also depends on goals of mutual relations among its participants. In terms of attitude to the event or fact that causes to disagreement, one or group of conflict's participants attempts to unilateral superiority, insistently persists on his position, that is they want to win. In this case, when they can not conjecture that the opposing party may compromise or they may fully or partially agree with the position of opposite side or if any parties' interests are ignored, then constructive solution of the problem becomes impossible and it converts to destructive conflict.

In classification proposed by Russian sociologist A.G.Zdravomislov (1995:105) conflicts divides into 8 main levels in terms of their participants: 1.Interpersonal;2.Intergroups;3.Inter-associations (parties); 4. Internal and institutional; 5. Among social divisions' sectors of labor; 6. Among state organizations; 7. Intercultural and among cultural types.

While explaining the meaning of "conflict", most authors refer to synonymic word sequence like "incompatibility", "struggle", "differences of opinion" and etc.

Any conflict, expresses in itself "confrontation moment", "struggle moment" without depending on its character, concrete meaning and kind. Military confrontation of neighbouring states, family disputes, official conflicts, strikes in front of enterprises, personal dramas- in all of these conflicts, the clash of contradictory or inappropriate interests, positions, tendencies and etc are observed. (Grishina, 2006:16).

According to our opinion, any of social problems is connected to human factor that is why the occurring of conflicts too, has a psychological essence that stipulating with mutual interaction factor among the people. Psychological conflicts, traditionally, are concerned to general psychological problems like inner world of human, intra-subjective and other 
intrapersonal events. In psychology of personality besides intra-personal conflicts, interpersonal conflicts are widely researched problems too. Interpersonal conflicts are confrontation situations, collisions, differences of opinions.

Historically, a different attitude of men and women to values' system of society,as 2 separate biological genders, their distinctions in behaviors, delights, enjoyment, requirements cause to form of imaginations about male and female stereotypes and role-gender behaviors. Naturally, biological inequality and contradiction in fact, are 2 inseparable parts of the whole. Their integrity creates social, psychological and moral integrity of person, and its common philosophical unity.

N.V.Grishina (2006: 25-86) concerns to main factors that conditioned by the intensity of role conflicts in family, the level of compliance and non-compliance of various role expectations (the behaviour required by the role); cruelty and ruthlessness related to the implementation of these requirements; personality characteristics of individual, his attitude to role expectations (installation, direction and etc.). "Husband expects that his wife will be his comrade, lovely spouse, housewife, mother of his children. He will use his proceeds for guaranty of family, may be his wife will also work, earn money and help to care family,even she will represent his family in society. But wife expects that, husband will be her lovely, spouse, provider of family, father and house owner. Both sides who expects to implementation of these functions, most of the time, imagine completely different character traits and types of activities. And they can be never combined in one person" (Mammedzade, 2004:56).

The conflicts occurring in communication process among the people are divided into two groups: functional (role, practical, formal) and interpersonal (Kunetsina, 1991: 13). Role conflict- is a conflict type arising from incompatibility of different role positions of personality and turning into serious problem for human. As a typical kind of widespread individuals' conflicts between roles, the conflicts connected with family roles, are going to occur when a man cannot fulfil his obligations as father or husband in family, or deviates from this, also on the basis of inability to perform the role of female (wife, mother) of working women. Russian psychologists U.E. Alyoshina and E.V.Lektorskaya, (1889, №5: 87) who researched the characteristics of working women's role conflicts in the family, have determined that role conflict of women principally differs for expressiveness signs of life condition. Role conflicts of women, distinguished by their professionalism at work, are more acute in comparison to the role contradictions of men of opposite sex.

Russian psychologist V.P.Sheynov (2011: 510-511) considers that motives of family conflicts are related to the following determinants:

- the lack of ideal partner, disappointment;

- an attempt to subordinate others;

- violence in family;

- intolerance to the husband's (wife's) habits, attempts to correct him or her; consumer attitude towards love, egoism;

- money;

- dissatisfaction with intimate relationships;

- incompatibility in imagines about man and woman roles;

- unequal division of houseworks between husband and wife;

- the lack of communication skills;

- harmful habits (first of all drunkenness);

- bad mutual relations with close people;

- different approaches to upbringing of children; 
- jealousy

During survey questionnaires with 300 married couples, in relation to research, $80 \%$ of respondent men and $67 \%$ of women gave negative answer to the question of "Is it possible to avoid conflicts in the family?" This fact gives ground to say that durability and stability of intra-family relations firstly depends on the purpose of marriage motives. If these motives are different in men and women and the family is not grounded by love motives, then occuring of many problems in relations between husband and wife will be unavoidable. Light attitude to marriage, differences in tendencies to wealth and psychological problems have special effect on occurring intra-family conflicts.

Most coincidental family conflicts are husband-wife and daughter-in-law-mother-inlaw conflicts which lead to severe results if cannot be solved by constructive way. Husbandwife conflict is a special kind of family conflicts. They occur on the ground of ethic relations between married couples, biopsychological incompatibility, different thoughts about children upbringing, relations with relatives and etc. According to L.M.Gurbanova (2013:78) the reasons of husband-wife conflicts are related to 3 main factors:

1)improper distribution of labor activity; 2) non-payment of material and moral requirements; 3) mental-physical discrepancy

But there are many other factors effecting to emergence of husband-wife conflicts, that here we can concern crisis periods in family development. First year of marriage life is characterized with conflicts arising from adaptation of couples, or on the basis of such conception-turning from two "me" into one "we". During this period there occurred evolution of feelings, love weakens a little, and couples stand in front of each other as what they are.

The second crisis period of family life is related to birth of children. New family system which has not yet fully strengthen is going to face a serious testing. During this period most observed conflicts are related to work or education of husband and wife, personal leisure or enjoyment. Tiredness of woman because of caring children can lead to temporal weakening of sexual activity. In early time of family life, that we are talking about, usually the risk of conflicts between spouses and their parents begins to increase relating to children's upbringing. Conflicts are more commonly encountered in the middle age stage of couples'life and this is the third period of family life. Such kind of conflicts, are usually related to monotonous life style. There occurred a new deficiency of impression in couples, and this is characterized by gradually getting ordinary of couples to each other. We can call this "become satisfied from old impressions, excessive desire for new impressions". Fourth stage of husband-wife conflicts in family there can be encountered after 18-24th years of their joint life. These conflicts are usually related to getting closer to the old age, occurence of loneliness feeling, children's moving away from the family, strengthening of emotional dependence in woman and etc. During this period, there occurred conflicts between couples on the basis of the possibility of husband's attempts to provide his sexual needs outside ("still it is not late") or in the reality background of this situation.

As the results of our researches we can certify that, in the conflicts between husband and wife, the affecting probability of external factors has an important role too. Here we can attribute the deterioration of financial situation of family as a result of increasing insolvency, excessive work load of both couples or one of them, the inability to find a job or unemployment of any spouse, the lack of separate home for a long time, difficulties associated with the placement of the children in the kindergarten, presence of a disabled member in the family, or problems related to lying sick and imprisoned family member and etc. Basing on results of our researches we can concern following conflict reasons in Azerbaijani families: 
- the lack of mutual love and respect;

- any of couple's dissatisfaction with sexual intimate life, biorhythm difference;

- insult of personal dignity, resentment, disrespectful and careless attitude, permament criticism;

- laziness, untidiness and querulousness of woman;

- a lack of positive emotions on the parties (lack of care and attention, psychological alienation, emotional insensitiveness);

- leadership longing;

- taking a fancy to alcohol, gambling, narcomania for which spent much money

- difference of opinion on financial matters;

- labor division problems;

- childlessness;

- discrepancy in interests, fun, delight.

As most widespread conflicts in modern Azerbaijani family, intergenerational conflicts attract the attention with their acute natures.Here we can add the conflicts among close relatives in the family, representing different generations, for example "mother in law-daughter in law, sister of mother-sister of father, children-parents, adopters-guardians, stepfathers and stepmothers-step children. As a special type of family conflicts, these conflicts significantly impact to the nature of mutual relations between parents and children. It is impossible to find any family, where there cannot be encountered children-parents conflicts. It is necessary to note that, a definiton given above to the concept of conflict can be concerned to intergenerational conflicts too. Intergenerational conflicts in society occur on the basis of discrepancies' and interests' collision of among generations of different age groups.

Last years in Azerbaijan divorce cases and child-births outside marriage, marriages with aliens, marriages of underages are intensifying, and of course it creates a serious concern. Over the last 8 years, divorce cases increased of 2 times and reached $22 \%$, but among the young people these indicators reached to $30 \%$. Only in 2014 year more than 4 thousands of people entered into early marriage. In 2017 year, in our republic there had been registered more than 30 thousands of child-births outside marriage. As the reasons of divorce there can be showed mostly, financial problems, childlessness, jealousy, betrayal, and in most cases, problems regarding to relations between husband and wife. In the reality of modern society, such a tendency is getting stronger that divorce is not wrong thing but a right choice. Loyal attitude to divorce among the young people is one of social events occurring as a result of liberalization of these cases in society.

In modern age, alongside a number of new and progressive traiditions in family relations, but in many families psychological alienation, persistent conflicts, and on the basis of these, domestic violence and divorce cases are going to increase rapidly.

It is important to have a certain imagination about development dynamics and stages of conflicts to solve them. In existing literatures there have been studying 4 stages of conflicts: 1) pre-conflict stage (in this stage there occurred contradictions between conflict sides and tension is gradually going to increase); 2) conflict stage ( conflict begins, contradiction is getting stronger); 3) conflict resolution stage ( in this stage conflict ends with the agreement of the parties or defeat of one of them, or turns into endless disagreement); 4) post-conflict stage ( normal relation of parties is restored, or conflict begins in adverse conditions). It is necessary to pay attention to the last stage of conflict, that no any fertile condition may arise for conflict, parties may draw closer to each others. 
Many recommendations have been made in order to normalize mutual relations between husband and wife, to prevent tension in conflict situations (V.Vladin, S.Kapustin, I.Dorno, A.Egides, V.Levkovich, Y.Ryurikov, L.A.Xoroshko, V.A.Reznikov, K.M.Shiriyeva, A.T.Aliyev, L.A.Suleymanova, A.S.Bayramov, A.A.Alizade, R.H.Mammedzade and etc.)

\subsection{Result}

Constructive solving way of conflicts between husband and wife, firstly, depends on the ability of couples to understand, forgive and compromise each other. The main terms of the completion of conflicts with a positive ending, is the absence of claim to win in any of the parties. "Success" over the defeat of your loved one cannot be called a victory. First of all, there should be treated with respect to others, not to put the blame on them. Incredible maximalism and determination are unacceptable for argumentation of his position and self-defense during conflicts. In such situations to take a step towards a mutual agreement, not to involve relatives, children, friends, neighbours in the conflict are more advisable. Because the prosperity and happiness of the family depends on husband-wife couple and their having a feeling of common destiny, who create the foundation of family hearth.

\section{REFERENCES:}

A.G.Zdravomislov Sociology of conflicts: Russia on the way of crisis overcoming; Moscow: Accept-Press, 1995.

D.Karnegi. How to find the way out of any conflict./ Translation from English L.G.Tretyak2nd edition-Minsk; Popurri, 2014.

D.Karnegi. How to get friends and how to affect people.Baku; "Adiloghlu” Publishing House, 2009.

E.B.Sidorenko Personal influence and confronting external influences//Psychological

E.G., Eidemiller, V.Yustichkis Psychology and psychotherapy of family.4th edition-

K.M.Shiriyeva. Family conflicts in south region of Azerbaijan and their psychological analyze /Dissertation's synopsis of thesis submitted for claim of scholarship degree on candidate of psychological sciences. Baku;1998.

L.M. Gurbanova. Psychological problems of family and ways of their solution. Sumgait, "Bilik" Publishing House, 2013.

N.V.Grebennikov Basics of family life. Moscow, "Prosvesheniye", 1991.

N.V.Grebennikov. Ethic and psychology of family life/ Studing resource for teachers; Moscow "Prosvesheniye", 1984.

N.V.Grishina Psychology of conflicts Saint Petersburg; Piter, 2006.pg.123-142.problems on self-realization of personality/under ed.A.A.Krilova.Moscow; 1997.

R.H.Mammedzade. Conflicts, families, schoolchildren. Baku; "Muallim” Publishing House, 2004.Saint Petersburg: Piter, 2009.

U.E.Alyoshina, E.V.Lektorskaya Role conflicts of working women//Psychological questions. 1989, № 5.

V.A.Petrovskiy Popular conversations on psychology. Moscow; "Pedagogy", 1983

V.N.Kunitsina Difficulties in communication among men; Dissertation's synopsis of thesis submitted for degree competition on doctor of psychological sciences- Saint Petersburg, 1991.

V.P. Sheynov Women plus men: Comprehension and conquest .Moscow.Act.,2011. 